\title{
IMPLICATION OF GST ON SMALL INFORMAL GARMENT BUSINESSES IN SPATIAL BUSINESS CLUSTER
}

\author{
Tirthankar Das \\ Department of Business Administration \\ Eminent College of Management and Technology \\ Barasat, Kolkata, West Bengal, India
}

\author{
Rahul Ray \\ Department of Business Administration \\ Eminent College of Management and Technology \\ Barasat, Kolkata, West Bengal, India
}

\author{
Sayan Chakraborty \\ Student, BBA $3^{\text {rd }}$ Year $5^{\text {th }}$ Semester \\ Department of Business Administration \\ Eminent College of Management \& Technology \\ Barasat, Kolkata, West Bengal, India
}

\begin{abstract}
The present paper is an effort to examine the consequences of GST particularly on small informal businesses especially on garments in spatial structures in India. The significance of the study lies in selecting a region, namely Sodpur, Naihati, Titagarh in Kolkata, dominated with small garments businesses which suffered the most immediately after the event of GST implementation due to sudden unexpected rise in the rate of taxation which lead to increase in the price of garment products. Our paper is a mere effort to detect sudden losses on small informal garments businesses due the absence of technological knowledge of the businessman in which they are unable to pay GST on garment products. The study is based upon primary data collected through purposive random sampling, then compared and analyzed in order to refer the influences of GST on a small urban informal economy.
\end{abstract}

Keywords - Informal businesses, Taxation, GST.

\section{INTRODUCTION}

The implementation of GST is a colossal concept which proclaims the giant structure for enhancing the economic development of a country. In the year 2000 our Prime Minister introduced the concept and started discussion on GST by empowering the committee head of Asim Das Gupta (West Bengal Chief Minister) to design the GST model idea of GST was proposed to remove all inefficient and discretionary taxes to obtain single nation taxation.

GST is an indirect tax which is imposed at every step in production process. It is collected on the point of consumption i.e. the impact and incidence of the tax is passed to some other persons who ultimately bears it. Generally, these taxes are collected from sellers, manufacturers and the importers. These taxes are divided into five different tax slabs for collection 5 per cent, 12 per cent, 18 per cent and 28 per cent. According to Economic Times on January 2, 2020 the revenue earned by the central and state government in December Rs.1.03cr. The number of taxpayer increases more than 50 per cent with 34lakh businesses.

However, GST is regarded as single taxation system but in reality it is regarded as dual aspect of taxation in which tax which is collected by the central government is regarded as Central Goods and Services Tax (CGST) and tax which is collected by state government is regarded as State Goods and Services Tax (SGST). This dual aspect of taxation creates economic as well as political issues for which total GST on goods is 20 per cent where 12 per cent is levied by the central government while remaining 8 per cent is levied by state government. According to UN report the effect of GST has lowered the country growth rate projection to 6.7 per cent in 2017 from 7 per cent in 2016. According to the report proclaim by World Bank GST is one of the most complicated tax system in the world, India has the highest standard GST rate in Asia the subset of goods and services is traded at 28 per cent.

With this scenario, our paper is a mere effort to examine the consequences of GST considering special emphasis on small informal business especially on small garments shops. For this purpose we have purposively selected small informal garments shops on the region of Sodepur, Naihati, Titagarh in the nearby areas of Kolkata during our sampling to make the study a convenient one. This is because the areas are adjacent beside the river Ganga and also the area is cluster of small informal garments shops where GST is implicated on sales outlets not on production. With this view our paper is a mere effort to detect the effect on GST on small informal garments 


\section{International Journal of Engineering Applied Sciences and Technology, 2020 \\ Vol. 5, Issue 7, ISSN No. 2455-2143, Pages 189-193 \\ Published Online November 2020 in IJEAST (http://www.ijeast.com)}

businesses to sudden unexpected rise in price of the garments products in which most of the businessman unable to pay GST due to lack of technological knowledge to pay GST-the incitement is still continuing through the pace of negative influences are at diminishing pace over time, as per our primary survey results.

\section{LITERATURE REVIEW}

Sabari Nath (2019) in his research study, "Implementation of GST in India Emerging Opportunities and Challenges", mentioned that the GST will reduce distortion price due to tax policies and reduce the burden of tax player. The dual effect of taxation reduces many central and state taxes and few Indian industries are not able to compare in the global market because of various limitations of indirect taxes.

Megha Agarwal (2019) in her study, "Study of Leading Sector of Indian Economy After GST Implementation" concluded that the main purpose to implement GST was to remove the effect of taxes and create a one common supportive and undivided Indian market which help to make the economic stronger. Thus the implementation of GST in Indian framework will lead to commercial benefit which were untouched by the VAT system and would essentially lead to economic development.

Arpit Shailesh (2016) in his work, "A Study on Impact on Impact Economy: A Key Tax Reform" mentioned that GST is helpful for the development of India economy which helps in improving the gross domestic product of the country. Thus GST offers the best option to broaden our tax base in which it helps in removing economic distortion by current indirect tax system and expected to encourage unbiased tax structure which is indifferent to geographical location.

Sanjay Dawn (2017) in his study "Goods and Services Tax in India" stated that GST will increase the burden of taxes for small and medium size entrepreneurs and also for traders who are facing several problems to submit tax due to lack of infrastructural development. GST will greatly help to overcome economic confusion which was caused by the complex tax structure.

Abhishek Kumar Yadav (2018) in his study, "Indian Goods and Services Tax:A Review of its Introductory Stage and its Possible Contribution Towards Sustainbale Economic Development" stated that GST is most important destination and consumption based indirect tax which is charged over the supply of goods and services in which manufacture will get the benefit of tax credit, thus the tax burden on producer will reduced which led to foster growth through more production.

Ranjana Upashi (2017) in her work "GST: Awareness and Preception of Small Business Person" emphasize that implication of GST on electronics goods, restaurants bills are going to be cheaper and costlier in the market. The implementation of system is also benefitting the consumer business and finally the economy is going on proper growth. The impact of GST in some sector is neutral and positive in which the economical cost of services are increasing with the increase rate of taxation from $15 \%$ to $18 \%$.

Davinder Kaur (2018) in her research study, "Goods and Services Tax in India" mentioned that the principal aim of GST is to eliminate cascading effect i.e. tax on tax and it will lead to bringing about cost competitiveness of the products and services both at the national and international market.

Vikram Sandhu (2019) studied "Goods and Services Tax: Issues and Challenges in India" and concluded that GST model should not able to increase the growth and revenue it will raise consumer inflation. Petroleum products, real estate and liquor are free from GST. Some products and services are tilled kept out of the GST.

Aakansha Uppal (2019) in her study "GST: Awareness and Preception of Small Business Person" mentioned that GST regime will increase the competitiveness of India in the global market as custom duties applicable on exports is removed hence it reduce the cost of transaction. It will also expand the fiscal space and improve the economy viability of the government. The government should also communicate with the SBPs through various online and offline platforms.

M.Jayalaxmi (2018) studied "Impact GST on Micro, Small and Medium Enterprises" and concluded that impact of GST and MSMEs is increasing the formalization of the Indian especially through digitization procedures under GST. Registration payments, refunds and return will now be carried out through online portals only. However SMEs need not worry about interacting with officers for carrying out the compliance.

Poonam (2018) in her research study "Goods and Services Tax in India" mentioned that GST play an important role as it improves the International level cost competition of various native Goods and Service. Implementation of GST on Indian products became more competitive in the domestic and international market.

Meenakshi Bindal (2018) in her work "Imact of GST on Indian Economy" emphasize that India has seen the strongest tax reform that aims to do away with various - tax system on goods and services and bring them under one rate.GST mechanism is designed in such a way which is expected to generate goods amount of revenue for both central and state government.

Rana Zehra Masood (2018) studied "GST and its Impact on Indian Economy" and concluded that the current taxes like sales tax, entertainment tax, vat, and other states tax will be included in GST which benefits the consumers as the cost of products will decrease which led to increase in demand of the products. The negative impact of GST is tax neutrality will not differentiate taxes on luxury goods and normal goods in which the state and central government levy higher taxes on luxury goods and services. 


\section{International Journal of Engineering Applied Sciences and Technology, 2020 \\ Vol. 5, Issue 7, ISSN No. 2455-2143, Pages 189-193 \\ Published Online November 2020 in IJEAST (http://www.ijeast.com)}

\section{BRIEF PROFILE}

Sodepur is a neighbor of Kolkata in the North 24 paganism districts in the Indian state of west Bengal. It is a part of the area covered by Kolkata Metropolitan Development Authority. Sodepur in the Barrackpore subdivision is historically famous for the khadi prathistan where historic decision with regard to freedom struggle was taken by Gandhiji and other great leader like Subhas Chandra Bose. The place is surrounded by shopping malls with big brands like peter England, Raymonds to supermarket like Reliance fresh and Vijay Sagar, the place is also hang around with eating places like KFC, Pizza Huts and more.

Naihati is a city and municipality of North 24 Parganas district in the Indian state of West Bengal. Naihati Municipality is one of the oldest in the whole country and was established in 1869. It is the birth place of Bankim Chandra Chattophyay, the author of India's national song Vande Mataram. As per the 2011 census of India, Naihati had a total population of 27,900, of which 109,849 50 per cent were males and 108,051 50 per cent were females. A city comprises male literacy is 79 per cent and female literacy is $70 \%$ and the total number of literates in Naihati was 173,397. The Fish culture at Naihati, Battala area is also notable for fish farming, rearing of sweet fish seeds of various geneses like Rui, Katla, Koi, Magur, Pabda and many more. Naihati is famous for cotton industry. As per reporting on GST of the local people during the field survey the place is dominated with self employed trader and small businessmen.

Titagrah is a city and a municipality of North 24 parganas district in the Indian state covered by Kolkata Metropolitan developed authority. As per 2011 Census of India, Titagarh had a total population of 116,541 , of which $62,735(54 \%)$ were males and 53,806 (46\%) were females. The Titagarh Paper Mills were set up at Titagarh in 1882 and India's leading manufacturer of specialty papers, currency note paper, and newsprint. On conversation with local shopkeepers they reported the implication of GST has good impact on the Indian economy.

\section{MAJOR RESEARCH QUESTION}

The prime objective of the proposed study is to detect the influences of the event of GST on small informal garment businesses in the region, namely Sodpur, Naihati, Titagarh in Kolkata. The selection of small informal garment businesses is particularly on the basis of theoretical spectrum inferences in the neo-classical development economics literature.

\section{METHODOLOGY}

The research is based on the primary survey. The study adopts the collection of primary data through both qualitative and quantitative procedures. The survey is conducted with a sample size of 50 with semi-structured questionnaire with direct and indirect interview method. The purposive random sample survey is conducted on the nearby areas Sodepur, Naihati and Titagarh.

\section{THE STUDY}

The present study approaches to examine the imposition of ambiguous taxation. GST has increased tax burden, hereby reducing profit margin even let losses. It led to closing down of 25 per cent of production units of the total sample size. Our study reveals that the implementation of GST is influencing small businesses by reducing profit and sales approximately 10-25 per cent therefore 12.5 per cent of the samples have reported that online transactions of finished products has increased however sellers are selling the products keeping in fact paying tax from their pocket which reduces the profit margin.

Some businesses are being closed down due to initial complexity in tax payment structure around 25 per cent of the sample have reported that they pay tax on purchase of products for sale from the wholesalers, vendors but do not collect tax from consumer however the customers are not ready to pay taxes but the sellers have to pay taxes on their purchase which leads to a major cause on mounting losses in the business.

\section{A. MALE-FEMALE WAGE DISTRIBUTION}

\begin{tabular}{|l|l|}
\hline Sex & Average wage (Rs) \\
\hline Male & $10,000-20,000$ \\
\hline Female & $7000-10,000$ \\
\hline
\end{tabular}

Table A. [Source: Field survey]

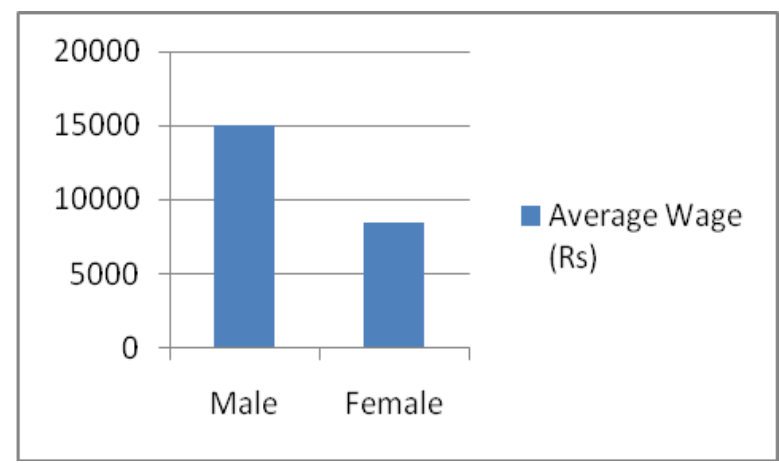

Fig A. [Source: Field survey]

The average wage of the male workers seems to be 10,000 20,000 whereas the average wage of the female workers is 7,000-10,000. Through the survey report it has been observed that there is proper working conditions for both male and female workers. There is a proper transportation facility available for both male and female workers. Both male and female workers get regular wages on time.

\section{B. WHETHER GST PAID BY THE SELLERS}


International Journal of Engineering Applied Sciences and Technology, 2020

Vol. 5, Issue 7, ISSN No. 2455-2143, Pages 189-193

Published Online November 2020 in IJEAST (http://www.ijeast.com)

\begin{tabular}{|l|l|l|}
\hline & No of Respondents & Percent \\
\hline Yes & 14 & 28 \\
\hline No & 30 & 60 \\
\hline Cannot Say & 6 & 12 \\
\hline Total & 50 & 100 \\
\hline
\end{tabular}

Table B. [Source: Field survey]

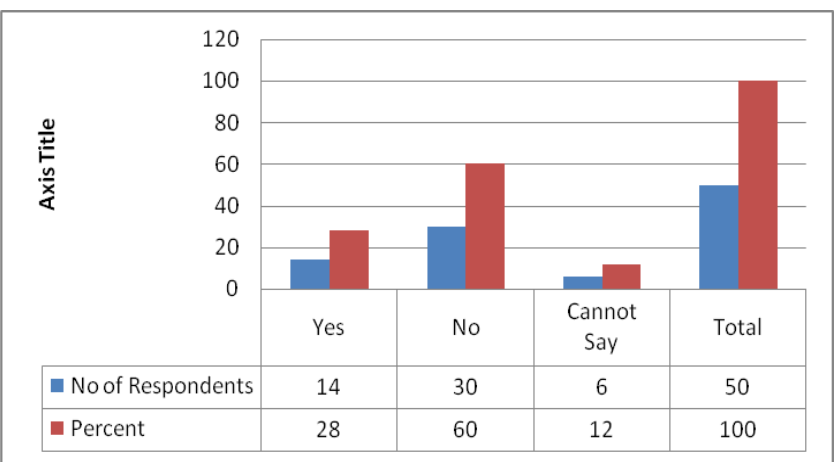

Fig B. [Source: Field survey]

Around 28 per cent of the respondents have said that they pay GST regime. It has been observed that 60 percent of respondents have reported that they do not pay GST. Many of the businessmen unable to pay GST due to lack of proper institutional set up and knowledge. However these businesses do not have proper concern with the new tax provisions to create a provision of GST.

\section{INFLUENCE OF GST ON PRICE}

\begin{tabular}{|l|l|l|}
\hline & No of Respondents & Percent \\
\hline Yes & 30 & 60 \\
\hline No & 16 & 32 \\
\hline Cannot Say & 4 & 8 \\
\hline
\end{tabular}

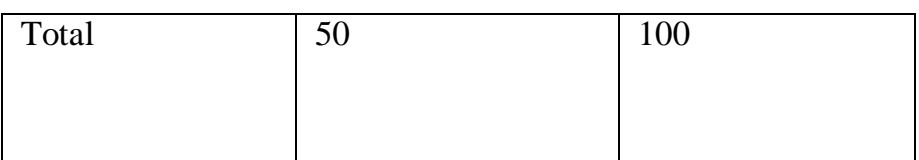

Table C. [Source: Field survey]

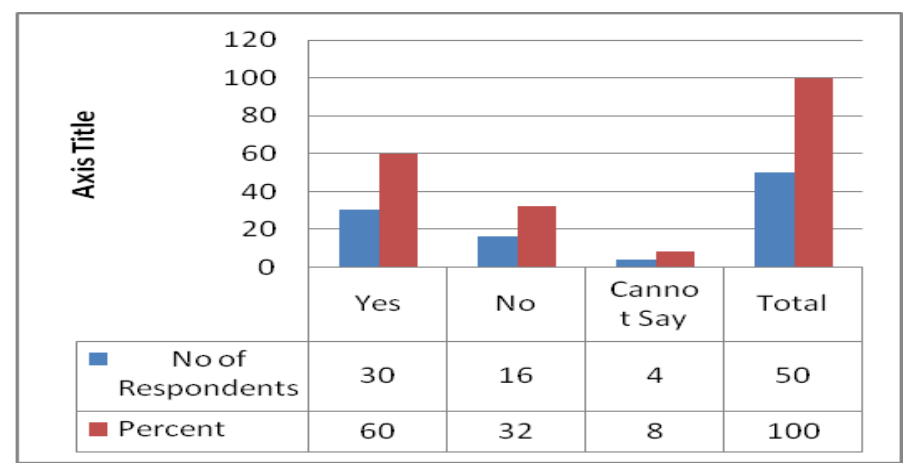

Fig C. [Source: Field survey]

Around 60 per cent of the respondents have reported that there is an influence of price for several garments products immediately after the implementation of GST. It has been observed through the survey report that around 32 per cent of the respondents has said that there is no influence of price. Therefore various provisions of GST are still ambiguous. Classification of goods and services along with their price are still not clear.

\section{IMPACT ON ECONOMY}

\begin{tabular}{|l|l|l|}
\hline & No of Respondents & Percent \\
\hline Yes & 34 & 68 \\
\hline No & 12 & 24 \\
\hline Cannot Say & 4 & 8 \\
\hline Total & 50 & 100 \\
\hline
\end{tabular}

Table D. [Source: Field survey] 


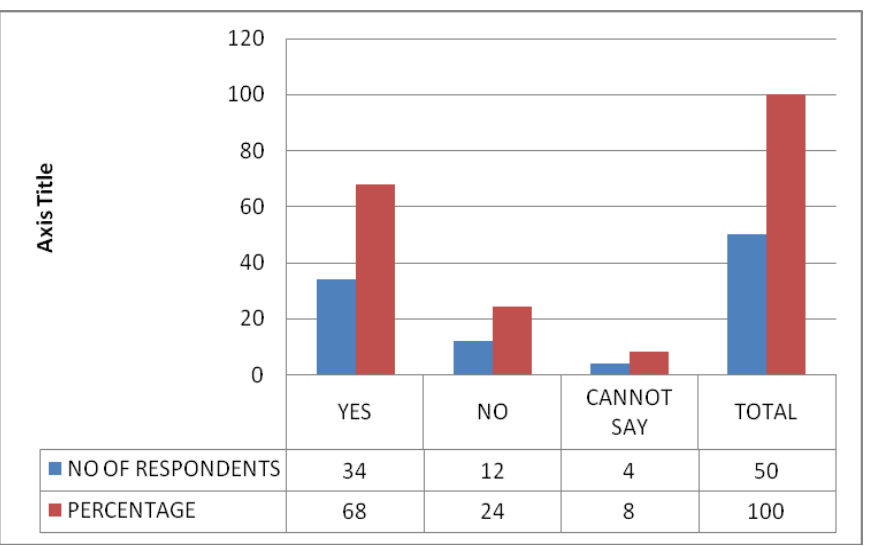

Fig D. [Source: Field survey]

Our study reveals that 68 per cent of the respondents have said that they there is a severe impact on the economy. Only 24 per cent of the respondents have revealed that there is no such impact on the economy. Therefore, the implication of GST has some serious impact for the small informal garments business in the regional economy in which small business has suffered immediately after the implementation of GST.

\section{CONCLUSION}

Being the biggest tax reform in India our paper concludes that implementation of GST has increased tax burden, hereby reducing profit margin even let losses. Our study reveals that around (60 percent) of the respondents have reported that they do not pay GST on garment products. Around ( 60 percent) of the respondents has said that there is an influence of price for different products of garments immediately after the event of GST. Some businesses are being closed down due to initial complexity in tax payment structure in which tax rates of some commodities has been increased which led to increase in the operating cost of goods and services. Therefore (68 percent) of the respondents have reported that GST has some serious impact on the economy in which small garment businesses has suffered immediately after the implementation of GST.

\section{REFERENCES}

[1] Agarwal, Megha. "Study of Leading Sector of Indian Economy After GST Implementation." Indra Management Review, 2019.

[2] Bindal, Meenaksi. "Imact of GST on Indian Economy." International Journal of Engineering and Management Research, 2018.

[3] Dawn, Sanjay. "Goods and Services Tax in India." EPRA International of Economic and Business Review, 2017.

[4] Kaur, Davinder. "Goods and Services Tax in India." Zenith International Journal of Multidisciplinary Research, 2018.
[5] M.Jayalaxmi. "Impact GST on Micro, Small and Medium Enterprises." International Journal of Engineering and Mangement Research, 2018.

[6] Masood, Rana Zehra. "GST and its Impact on Indian Economy." International Journal of Transformation in Accounting, Auditing and Taxation, 2018.

[7] Nath, Sabari. "Implementation of GST in India Emerging Opportunities and Challenges." Journal of Research and Management, 2019.

[8] Poonam. "Goods and Services Tax in India." 6th International of Conference on Recent Trends in Engineering, Science and Management, 2018.

[9] Sandhu, Vikram. "Goods and Services Tax: Issues and Challenges in India." International Journal of Recent Technology and Exploring Engineering, 2019.

[10] Shailesh, Arpit. "A Study on Impact on Impact Economy: A Key Tax Reform." International Journal of Commerce and Management Research, 2016.

[11] Upashi, Ranjana. "Study of Effects of GST on Different Sectors in India." Elk Asia Pacific Journal of Finance and Risk Management, 2017.

[12] Uppal, AAkansha. "GST: Awareness and Preception of Small Business Person." International Journal of Innovative Technology and Exploring Engineering, 2019.

[13] Yadav, Abhishek Kumar. "Indian Goods and Services Tax:A Review of its Introductory Stage and its Possible Contribution Towards Sustainbale Economic Development ." International Journal of Management Studies, 2018. 